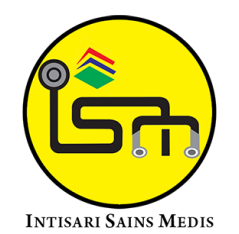

Published by Intisari Sains Medis

\title{
Pria 80 tahun dengan tumor ganas dinding dada: laporan kasus
}

\author{
Raissa Andi Soekrisno ${ }^{1 *}$, Dewa Gde Mahiswara Sudiatmika², \\ Elysanti Dwi Martadiani ${ }^{2}$, Firman Parulian Sitanggang ${ }^{2}$, Herman Suputra ${ }^{3}$
}

1PPDS-1 Radiologi, Fakultas Kedokteran Universitas Udayana-RSUP Sanglah Denpasar, Bali-Indonesia ${ }^{2}$ Departemen/KSM Radiologi, Fakultas Kedokteran Universitas Udayana-RSUP Sanglah Denpasar, BaliIndonesia

${ }^{3}$ Departemen/KSM Patologi Anatomi, Fakultas Kedokteran Universitas Udayana-RSUP Sanglah Denpasar, Bali-Indonesia

\section{*Korespondensi:}

Raissa Andi Soekrisno; PPDS-1 Radiologi, Fakultas Kedokteran Universitas Udayana-RSUP Sanglah Denpasar, Bali-Indonesia;

raissa.andis@gmail.com

\section{Diterima: 29-08-2021}

Disetujui: 02-12-2021

Diterbitkan: 13-12-2021

\section{ABSTRACT}

Background: Malignant tumors that form in bone, soft tissue, or cartilage, are called sarcomas. Symptoms of these tumors vary, and may include shortness of breath, chest pain, and swelling around the tumor. Imaging such as X-rays and CT scans can be helpful, although imaging features of the few malignant chest wall tumors that are less specific, knowledge of the typical radiographic manifestations of these tumors can often make it easier for experts to differentiate between benign and malignant tumors and help lead to a more specific diagnosis.

Case presentation: An 80-year-old man complains of a lump in the right chest. The results of laboratory tests showed anemia, decreased kidney function, and hypercalcemia. The CT scan of the thorax with contrast showed a solid mass in the right pleural

cavity infiltrating the surrounding chest wall muscles, bilateral pneumonia, and osteolytic lesions on the spine suspected of being a metastatic process or spreading malignancy. The results of the biopsy showed a diffuse morphological appearance of immature plasma cells with an approach to the diagnosis of cutaneous infiltration plasma cell myeloma with a differential diagnosis of plasmablastic lymphoma.

Conclusion: The results of X-ray imaging and CT scan of the thorax help narrow the differential diagnosis, where there is an image of a tumor on the chest wall with destruction of the surrounding bone and soft tissue and an image of infiltration into the pleura accompanied by multiple osteolytic images of the vertebrae. Assisted by a biopsy (anatomical pathology), the closest diagnosis in this patient is plasma cell myeloma chest wall.

\section{Keywords: chest wall tumor, plasmacytoma, plasma cell myeloma.}

Cite This Article: Soekrisno, R.A., Sudiatmika, D.G.M., Martadiani, E.D., Sitanggang, F.P., Suputra, H. 2021. Pria 80 tahun dengan tumor ganas dinding dada: laporan kasus. Intisari Sains Medis 12(3): 872-875. D0I: 10.15562/ism. v12i3.1127

\section{ABSTRAK}

Latar Belakang: Tumor ganas yang terbentuk pada tulang, jaringan lunak, atau kartilago disebut sarcoma. Gejala dari tumor ini bervariasi, dapat berupa sesak nafas, nyeri dada, dan pembengkakan pada sekitar tumor. Pencitraan seperti rontgen dan CT scan dapat membantu, walaupun gambaran pencitraan dari beberapa tumor ganas dinding dada kurang spesifik, pengetahuan tentang manifestasi tipikal pada radilogi dari berbagai tumor ini seringkali dapat memudahkan para ahli untuk membedakan jenis tumor jinak dan ganas dan membantu mengarahkan diagnosis yang lebih spesifik.

Kasus: Seorang laki - laki berusia 80 tahun dengan keluhan benjolan di dada sebelah kanan. Hasil pemeriksaan laboratorium didapatkan hasil anemia, penurunan fungsi ginjal, dan hiperkalsemia. Hasil CT Scan thorax dengan kontras menunjukkan adanya massa solid pada cavum pleura kanan yang menginfiltrasi otot dinding dada di sekitarnya, pneumonia bilateral, serta lesi osteolitik pada tulang belakang yang dicurigai sebagai suatu proses metastase atau penyebaran keganasan. Hasil biopsi menunjukkan gambaran morfologi sebaran difus sel plasma imaturmatur dengan pendekatan pada diagnosis cutaneus infiltration plasma cell myeloma dengan diagnosis banding plasmablastic lymphoma.

Simpulan: Hasil pencitraan rontgen dan CT scan thorax membantu menyempitkan diagnosis banding, di mana terdapat gambaran tumor pada dinding dada dengan destruksi tulang dan jaringan lunak di sekitarnya serta gambaran infiltrasi ke pleura disertai gambaran osteolitik multipel pada vertebrae. Dibantu dengan pemeriksaan biopsi (patologi anatomi) maka diagnosis yang paling mendekati pada pasien ini adalah plasma cell myeloma dinding dada
Kata Kunci: tumor dinding dada, plasmasitoma, plasma sel myeloma.

Sitasi Artikel ini: Soekrisno, R.A., Sudiatmika, D.G.M., Martadiani, E.D., Sitanggang, F.P., Suputra, H. 2021. Pria 80 tahun dengan tumor ganas dinding dada: laporan kasus. Intisari Sains Medis 12(3): 872-875. D0I: 10.15562/ism. v12i3.1127 


\section{PENDAHULUAN}

Dinding dada terbentuk dari tulang, kartilago, dan jaringan lunak. Tumor ganas yang terbentuk pada tulang, jaringan lunak, atau kartilago, disebut sarcoma. ${ }^{1}$ Keganasan dinding dada atau thorax meliputi berbagai tipe sarcoma termasuk plasmacytoma atau disebut juga plasma cell myeloma, yang merupakan kasus yang masih jarang terjadi. ${ }^{2,3}$ Berbagai gejala klinis dapat bervariasi tergantung dari jenis atau klasifikasi dan tingkat keganasan tumornya. Gejala yang paling sering ditemukan berupa sesak nafas, nyeri dada, dan pembesaran atau pembengkakan pada dinding dada di sekitar tumor tersebut. ${ }^{2}$ Rontgen thorax, pencitraan yang sering digunakan untuk evaluasi awal dapat membantu untuk mendeteksi destruksi korteks. Di samping itu, CT-Scan merupakan pemeriksaan radiologi lanjutan yang lebih sensitive daripada rontgen untuk mendeteksi matriks kalsifikasi tulang dan destruksi korteks. Meskipun gambaran pencitraan dari beberapa tumor ganas dinding dada kurang spesifik, pengetahuan tentang manifestasi tipikal pada radilogi dari berbagai tumor ini seringkali dapat memudahkan para ahli untuk membedakan jenis tumor jinak dan ganas dan membantu mengarahkan diagnosis yang lebih spesifik. ${ }^{2-4}$ Multiple myeloma jarang terkait dengan keterlibatan pulmonal. Keterlibatan pleura pada myeloma sangatlah jarang, dengan persentase kurang dari $1 \%$ dari seluruh pasien dengan plasma cell myeloma, dan memiliki prognosis yang buruk. Diagnosis yang tepat dapat mengurangi morbiditas dan mortalitas pasien., ${ }^{2,5}$

Laporan kasus ini akan mendiskusikan tentang pasien laki-laki 80 tahun dengan tumor ganas pada dinding dada yang dirawat di RSUP Sanglah, Denpasar.

\section{LAPORAN KASUS}

Seorang laki - laki berusia 80 tahun, datang ke RSUP Sanglah dengan keluhan benjolan di dada sebelah kanan. Pasien sudah cukup lama merasakan ada keluhan di dada sebelah kanan. Sebelum didapatkan benjolan pada dada bagian kanan, pasien mengeluhkan nyeri yang hilang timbul pada dada kanannya dan bertambah nyeri saat aktivitas berat. Keluhan semakin dirasakan dalam 3 bulan terakhir di mana benjolan dirasakan semakin membesar, semakin terasa nyeri, dan sering sesak terutama saat pasien berjalan menanjak atau naik tangga. Awalnya benjolan berukuran sebesar telur puyuh dan membesar hingga sebesar telur ayam. Nyeri dirasakan pada tulang dada kanan dan menjalar sampai ke bagian dalam rongga dada. Nyeri dirasakan terutama pada daerah munculnya benjolan sampai saat ini. Pasien juga sering mengeluh cepat lelah. Tidak ada keluhan diare, kaki bengkak atau lemas serta kesemutan. Keluhan bintik-bitnik merah di badan dan lidah bengkak.

Pasien 2 bulan sebelum ke RSUP Sanglah sudah memeriksakan diri di RSUD Klungkung, dilakukan pemeriksaan CT scan kemudian dilanjutkan dengan biopsi. Hasil pemeriksaan CT Scan (Gambar 1) dikatakan terdapat tumor di dinding dada dengan hasil biopsi berupa gambaran morfologi yang menunjukkan malignant round cell tumor dengan diagnosis banding berupa round cell sarcoma cenderung malignant glomus tumor dengan diagnosis banding mesothelioma.

Kemudian pasien dirujuk ke RSUP Sanglah untuk pemeriksaan dan tatalaksana lebih lanjut. Pasien memeriksakan diri ke Sanglah dan dilakukan pemeriksaan CT Scan thorax dengan kontras dan dilakukan biopsi lanjutan. Hasil CT Scan thorax dengan kontras (Gambar 2) menunjukkan adanya massa solid pada cavum pleura kanan yang menginfiltrasi otot dinding dada di sekitarnya, pneumonia bilateral, serta lesi osteolitik pada tulang belakang yang dicurigai sebagai suatu proses metastase atau penyebaran keganasan. Hasil biopsi menunjukkan gambaran morfologi sebaran difus sel plasma imatur-matur dengan pendekatan pada diagnosis cutaneus infiltration plasma cell myeloma dengan diagnosis banding plasmablastic lymphoma. Hasil pemeriksaan laboratorium didapatkan hasil anemia, penurunan fungsi ginjal, dan hiperkalsemia. Pasien dirawat inap selama 3 hari, kemudian diperbolehkan untuk pulang oleh DPJP yang merawat dan dijadwalkan untuk kontrol ke poliklinik. Pada follow up terbaru pasien dilakukan pemeriksaan laboratorium darah dengan hasil masih mendukung klinis di mana masih didapatkan anemia dan penurunan fungsi ginjal, serta pada tanggal 2 April 2021 didapatkan pula hasil biopsi sumsum tulang dengan hasil marrow plamacytosis.

\section{PEMBAHASAN}

Kasus keganasan dinding dada oleh infiltrasi sel plasma masih merupakan kasus sang sangat jarang tetapi tidak
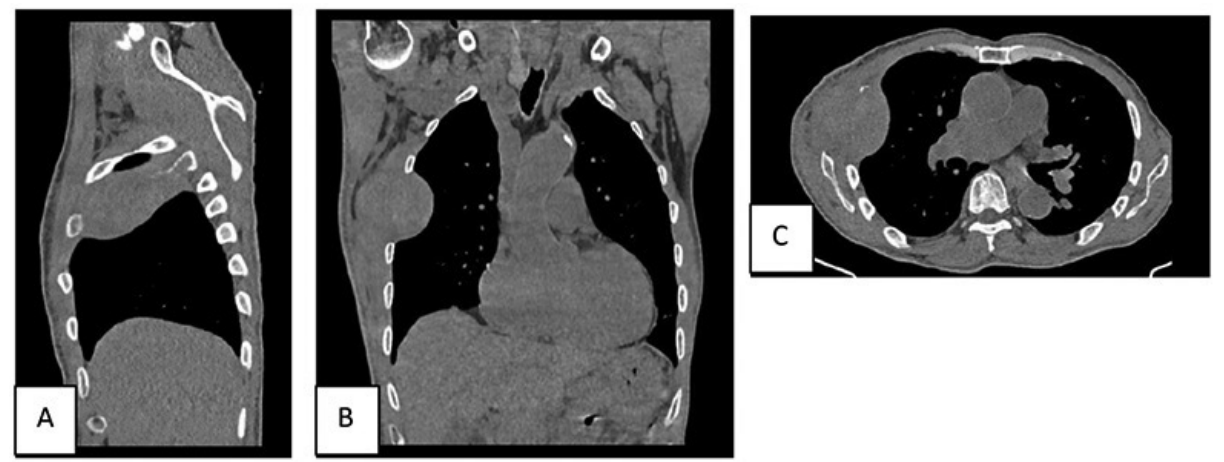

Gambar 1. CT scan Thorax; A. Gambar CT Scan Thorax Sagital; B. Gambar CT-Scan Thoraks Coronal; C. Gambar CT-Scan Thoraks Aksial

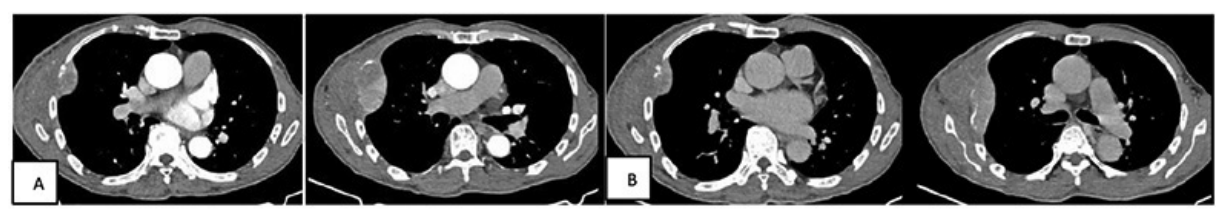

Gambar 2. A. CT-Scan Thoraks potongan aksial dengan kontras fase arteri, B. CT-Scan Thoraks potongan aksial dengan kontras fase vena 
dapat diabaikan. ${ }^{2}$ Tinjauan pustaka yang ditemukan pun lebih banyak berupa jurnal penelitian, laporan kasus, maupun artikel. Pengetahuan radiologi dapat membantu membedakan jenis tumor jinak dan ganas dan membantu mengarahkan diagnosis yang lebih spesifik. ${ }^{3,6,7}$

Pada pasien ini, laki-laki, usia 80 tahun, dengan kronologis perjalanan penyakit di mana pasien merasakan benjolan pada dinding dada dengan rasa nyeri yang semakin memberat dan sesak

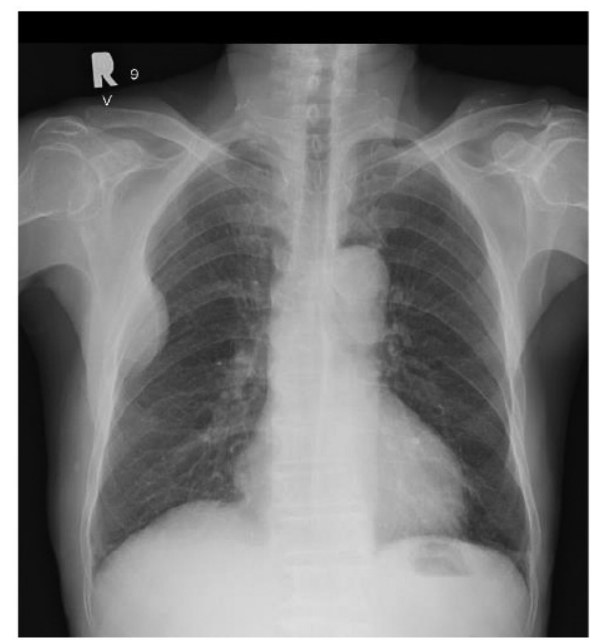

akhir-akhir ini dapat lebih mengarahkan untuk massa primer dari dinding dada atau extrapulmonal yang selanjutnya menginfiltrasi ke intrapulmonal., ${ }^{7,8}$

Hasil pemeriksaan radiologi rontgen thorax PA (Gambar 3) didapatkan kesan gambaran pleural mass setinggi costae 3-6 posterior kanan sisi lateral, dengan konsolidasi paru kiri suspek pneumonic type lung metastase, dan lesi osteolitik multipel pada vertebrae torakalis suspek metastastic bone disease. Pemeriksaan radiologi canggih berupa CT Scan thorax dengan kontras (Gambar 4) didapatkan kesan massa solid pleura kanan disertai destruksi anterolateral os costae 4 kanan dan infiltrasi $\mathrm{m}$. intercostal internal dan eksternal kanan hingga musculus serratus anterior kanan membantu menyempitkan diagnosis banding. Hasil pemeriksaan biopsi (patologi anatomi) lanjutan di RSUP Sanglah didapatkan hasil diagnosis yang paling mendekati adalah cutaneus infiltration plasma cell myeloma, dengan diagnosis banding plasmablastic lymphoma. ${ }^{9}$ Dan pada pemeriksaan penunjang laboratorium didapatkan anemia, gangguan fungsi ginjal, serta hiperkalsemia.9,10 Pasien dijadwalkan

Gambar 3. Rontgen Thorax PA
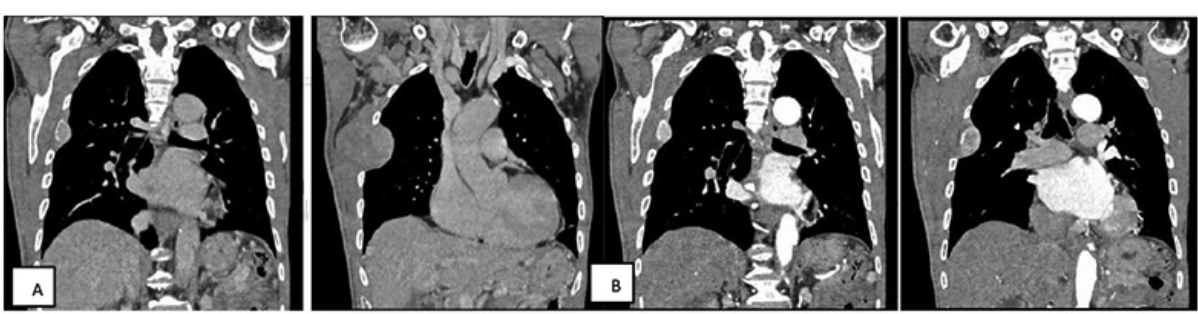

Gambar 4. A. CT-Scan Thoraks potongan koronal dengan kontras fase arteri, B. CT-Scan Thoraks potongan coronal dengan kontras fase vena

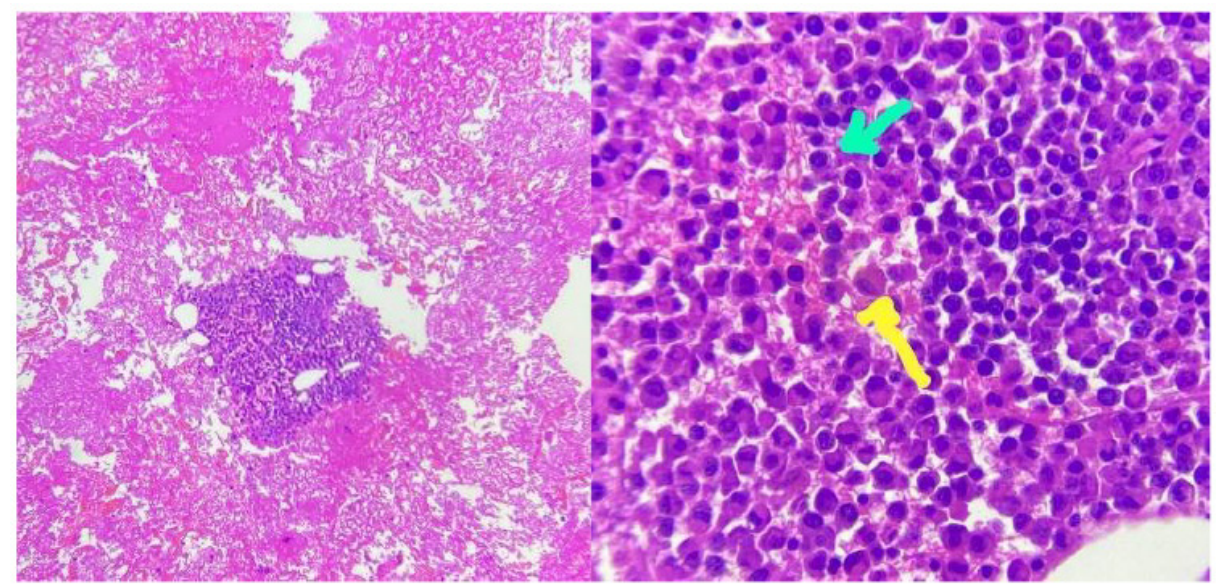

Gambar 5. A HE 40x (Tampak peningkatan jumlah sel plasma); B HE 400x (Panah hijau sel plasma matur, panah kuning sel plasma imatur). kontrol rutin di poliklinik bedah onkologi dan pada follow up terbaru dengan hasil laboratorium pada tanggal 31 Maret 2021 dan 1 April 2021 didapatkan hasil $\mathrm{Hb}$ pasien yang masih rendah (anemia) serta penurunan fungsi ginjal. Pada tanggal 2 April 2021 didapatkan pula hasil biopsi bone marrow berupa marrow plasmacytosis.

Dari anamnesis, pemeriksaan fisik, dan hasil pemeriksaan penunjang dapat mendukung dalam pendekatan diagnosis tumor ganas dinding dada berupa plasma cell myeloma dengan diagnosis banding plasmablastic lymphoma., ${ }^{2,8,11}$ Usulan dari tim bedah onkologi untuk pasien dilakukan pemeriksaan biopsi bone marrow dan imunohistokimia, dan pada follow up terbaru semakin mendekatkan pada diagnosis plasma cell myeloma dengan hasil laboratorium yang mendukung klinis dan hasil biopsi berupa marrow plasmacytosis (Gambar 5a dan 5b). ${ }^{9}$

Keputusan penatalaksanaan pada awalnya masih berupa non-operatif, di samping kasus yang masih jarang ditangani, dengan pertimbangan utama pengambilan massa sudah mendestruksi otot dan tulang di bagian dinding dada tersebut dengan pemikiran komplikasi yang lebih berat. Pasien kemudian dikonsulkan ke spesialis hemato-onkologi untuk rencana terapi sambil menunggu hasil biopsi sumsum tulang. Pada saat ini sudah didapatkan hasil biopsi sumsum tulang dan menunggu kontrol poliklinik kembali untuk mendapatkan tatalaksana yang paling tepat selanjutnya.

\section{SIMPULAN}

Tumor atau massa pada dinding dada dengan keterlibatan pleura dapat dibedakan dari primer di extrapulmonal dan intrapulmonal dengan berbagai diagnosis bandingnya. Pada pasien ini dengan jenis kelamin laki-laki usia 80 tahun, dengan kronologis perjalanan penyakit di mana pasien merasakan benjolan pada dinding dada dengan rasa nyeri yang semakin memberat dan sesak akhir-akhir ini dapat lebih mengarahkan untuk massa primer dari dinding dada atau extrapulmonal yang selanjutnya menginfiltrasi ke intrapulmonal. Hasil pemeriksaan radiologi foto thorax $\mathrm{PA}$ 
dan CT scan di RSUP Sanglah membantu menyempitkan diagnosis banding, di mana terdapat gambaran tumor atau massa pada dinding dada dengan destruksi tulang dan jaringan lunak di sekitarnya serta gambaran infiltrasi intrapulmonal minimal yaitu pleura disertai gambaran osteolitik multipel pada vertebrae, ditambah dengan hasil pemeriksaan penunjang dengan kerterlibatan gangguan fungsi organ, anemia, dan hiperkalsemia, dibantu dengan pemeriksaan biopsi (patologi anatomi) maka diagnosis yang paling mendekati pada pasien ini adalah plasma cell myeloma dinding dada.

Multiple myeloma jarang terkait dengan keterlibatan pulmonal. Keterlibatan pleura pada myeloma sangatlah jarang, dengan persentase kurang dari $1 \%$ dari seluruh pasien dengan plasma cell myeloma, dan memiliki prognosis yang buruk. Diagnosis yang tepat dapat mengurangi morbiditas dan mortalitas pasien. Menurut data yang didapatkan, terapi efektif pada pasien dengan kondisi seperti ini biasanya berupa pembedahan dilengkapi radioterapi dan atau kemoterapi.

\section{KONFLIK KEPENTINGAN}

Tidak ada konflik kepentingan

\section{PERTIMBANGAN ETIS}

Pasien telah menerima informed consent yang ditandatangani terkait publikasi data medis yang dimiliki pasien ke dalam jurnal medis.

\section{PENDANAAN}

Penulis tidak mendapatkan dana dari pemerintah ataupun lembaga swasta terkait publikasi dari laporan kasus ini.

\section{KONTRIBUSI PENULIS}

Seluruh penulis telah berkontribusi terhadap penyusunan naskah laporan kasus dan setuju terhadap versi final dari laporan kasus ini untuk dilakukan publikasi.

\section{DAFTAR PUSTAKA}

1. Tazi I, Nafil H, Mahmal L. Chest wall tumor at relapse of multiple myeloma. Afr Health Sci. 2013;13(1):160-1. Available from: https:// pubmed.ncbi.nlm.nih.gov/23658583

2. Abhishek K, Ejazi M, Hashim Z, Chaudhary R, Niharika K. Multiple myeloma with different thoracic manifestations: Case series. Indian J Respir Care. 2018;7(2):108. Available from: http://dx.doi.org/10.4103/ijrc.ijrc $11 \quad 18$

3. Tateishi U, Gladish GW, Kusumoto M, Hasegawa T, Yokoyama R, Tsuchiya R, et al. Chest Wall Tumors: Radiologic Findings and Pathologic Correlation. RadioGraphics. 2003;23(6):1477-90. Available from: http:// dx.doi.org/10.1148/rg.236015526

4. Ooi GC, Chim JC-S, Au W-Y, Khong P-L. Radiologic Manifestations of Primary Solitary Extramedullary and Multiple Solitary Plasmacytomas. Am J Roentgenol. 2006;186(3):821-7. Available from: http:// dx.doi.org/10.2214/ajr.04.1787
5. Bhandari S, Makaju R, Baral SR. Solitary plasmacytoma of rib: a rare presentation. Int Clin Pathol J. 2018;6(3). Available from: http:// dx.doi.org/10.15406/icpjl.2018.06.00172

6. Corwin J, Lindberg RD. Solitary plasmacytoma of bone vs. extramedullary plasmacytoma and their relationship to multiple myeloma. Cancer. 1979;43(3):1007-13. Available from: $\quad$ http://dx.doi.org/10.1002/10970142(197903)43:3\%3C1007::aidcncr2820430333\%3E3.0.co

7. Kadokura M. A Surgical Case of Solitary Plasmacytoma of Rib Origin with Biclonal Gammopathy. Jpn J Clin Oncol. 2000;30(4):1915. Available from: http://dx.doi.org/10.1093/ jico/hyd051

8. Kintzer JS. Thoracic and Pulmonary Abnormalities in Multiple Myeloma. Arch Intern Med. 1978;138(5):727. Available from: http://dx.doi.org/10.1001/ archinte.1978.03630290039015

9. Gopal MR. multiple myeloma presented as an anterior chest wall mass diagnosed by cytological examination: a case report. J Evid Based Med Healthc. 2015;2(8):1072-6. Available from: http://dx.doi.org/10.18410/ jebmh/2015/156

10. Mendenhall CM, Thar TL, Million RR. Solitary plasmacytoma of bone and soft tissue. Int $\mathrm{J}$ Radiat Oncol. 1980;6(11):1497-501. Available from: $\quad$ http://dx.doi.org/10.1016/0360$\underline{3016(80) 90006-1}$

11. Biruta W, Martin H. Lymphomas presenting as chest wall tumors. Operative Thoracic Surgery. CRC Press; 2006. p. 45-58. Available from: http://dx.doi.org/10.1201/b13418-8

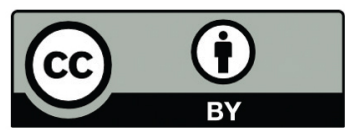

This work is licensed under a Creative Commons Attribution 